\title{
Manganese Accumulation and Tissue-level Distribution in the Australian Hyperaccumulator Gossia Bidwillii (Myrtaceae)
}

\author{
Farida Abubakari ${ }^{1}$ · Philip Nti Nkrumah ${ }^{1}$ - Denise R. Fernando ${ }^{2}$ - Peter D. Erskine ${ }^{1}$. Guillaume Echevarria ${ }^{1,3}$. \\ Antony van der Ent ${ }^{1,3}$ (D)
}

Received: 30 July 2021 / Accepted: 23 December 2021 / Published online: 19 February 2022

(c) The Author(s) 2022

\begin{abstract}
The manganese (Mn) hyperaccumulator Gossia bidwillii is a tree species native to subtropical eastern Australia where it occurs on Mn-rich soils. Here, we conducted the first Mn accumulation and tissue-level distribution study on wild and experimentally grown G. bidwillii. Gossia bidwillii plants were subjected to different levels of Mn $\left(250 \mu \mathrm{g} \mathrm{g}^{-1}, 500 \mu \mathrm{g} \mathrm{g}^{-1}\right.$, $1000 \mathrm{~g} \mathrm{~g}^{-1}$ ) soil dosing treatments, whereas the wild G. bidwillii was sampled from growing on highly Mn-enriched natural soils. We used laboratory-based micro-X-ray Fluorescence ( $\mu \mathrm{XRF}$ ) elemental mapping to elucidate in situ distribution patterns of $\mathrm{Mn}$ and other elements in hydrated wild and Mn-dosed G. bidwillii leaves. The data from wild G. bidwillii revealed that it can be strongly Mn-hyperaccumulating with foliar Mn concentrations of $39000 \mu \mathrm{g} \mathrm{g}^{-1}$ and $24000 \mu \mathrm{g} \mathrm{g}^{-1}$ in old and young leaves, respectively. In the Mn dosing trial, G. bidwillii accumulated $24400 \mu \mathrm{g} \mathrm{g}^{-1}$ in old leaves and $17100 \mu \mathrm{g} \mathrm{g}^{-1}$ in young leaves in the highest treatment level. The laboratory based $\mu$ XRF data revealed that Mn is uniformly enriched throughout the laminae and petioles of both young and old leaves in wild G. bidwillii; while in Mn-dosed G. bidwillii, the foliar Mn distribution was primarily concentrated at the leaf-tip and lamina. The approach employed by combining data from the field and controlled experiments was especially meaningful for investigating $\mathrm{Mn}$ accumulation in this species and gaining added insight into the phenomenon of Mn hyperaccumulation.
\end{abstract}

Keywords Elemental distribution $\cdot$ Hyperaccumulator $\cdot$ Manganese $\cdot$ Gossia bidwillii

\section{Introduction}

Hyperaccumulators are highly unusual plants that are able to concentrate extremely high concentrations of specific trace elements in their foliage and other aerial parts (Baker and Brooks 1989; Reeves 2003; van der Ent et al. 2013). They are able to attain such high levels of accumulation due to their enhanced uptake and translocation mechanisms that are yet to be fully understood (Baker 1981, 1987). Manganese

Communicated by: Jeremy Harbinson

Antony van der Ent

a.vanderent@uq.edu.au

1 Centre for Mined Land Rehabilitation, Sustainable Minerals Institute, The University of Queensland, Brisbane, Australia

2 Department of Ecology, Environment and Evolution, La Trobe University, Melbourne, Australia

3 Laboratoire Sols Et Environnement, Université de Lorraine-INRAE, 54000 Nancy, France
(Mn) hyperaccumulation is recognised at the notional threshold concentration of $10000 \mu \mathrm{g} \mathrm{g}^{-1} \mathrm{Mn}$ in dry weight shoot tissue (van der Ent et al. 2013). The hyperaccumulation of $\mathrm{Mn}$ is a rare trait documented primarily within the genera Alyxia (Apocynaceae), Denhamia (Maytenus) (Celastraceae), Gossia (Myrtaceae), Grevillea, Macadamia and Virotia (Proteaceae) distributed over eastern Australia and New Caledonia (Losfeld et al. 2015; Fernando et al. 2008, 2009b; Jaffré 1977, 1980), Malaysia (Nkrumah et al. 2018) and recently from Papua New Guinea (Do et al. 2019).

There are 20 Australian Gossia species with a wide latitudinal distribution, ranging from northern New South Wales $\left(32^{0} \mathrm{~S}\right)$ to the northern Cape York Peninsula $\left(13^{0} \mathrm{~S}\right)$ in Queensland (Snow et al. 2003). Gossia bidwillii (Myrtaceae) has a smooth bark which is irregularly covered with relatively large, coloured patches. This species, as well as G. acmenoides, G. lucida and G. grayi, are called "python bark Gossias" due to the resemblance of their bark to the skin colouring of the python snake (Snow et al. 2003). Gossia bidwillii is the only Australian Gossia to thrive 
on ultramafic soils (McLay et al. 2019), and also the first Mn hyperaccumulator described in Australia (Bidwell et al. 2002). That discovery instigated subsequent research on Mn hyperaccumulation in several other Australian Gossia species (Fernando et al. 2007, 2008a, 2009b, 2013; McLay et al. 2019). All these published studies have been based on freshly collected field samples or preserved material obtained from herbaria. There have been consistent observations in the Mn hyperaccumulative trait in Gossia bidwillii, as captured in a recent phylogenetic study of Gossia (McLay et al. 2019), and in fresh field material where foliar Mn concentrations reached up to 19 $200 \mu \mathrm{g} \mathrm{g}^{-1}$ in this species (Bidwell et al. 2002).

Recent growth experiments on $G$. fragrantissima have shown that it can take up to $545 \mu \mathrm{g} \mathrm{g}^{-1} \mathrm{Co}, 17400 \mu \mathrm{g} \mathrm{g}^{-1}$ $\mathrm{Mn}$ and $13000 \mu \mathrm{g} \mathrm{g}^{-1} \mathrm{Zn}$ (Abubakari et al. 2021a), whereas freshly collected field samples of $G$. grayi and $G$. shepherdii were observed to contain up to $13700 \mu \mathrm{g} \mathrm{g}^{-1}$ and $11000 \mu \mathrm{g} \mathrm{g}^{-1}$ foliar Mn, respectively (Fernando et al. 2018). In vivo cryo-scanning electron microscopy (SEM)/energy dispersive X-ray analysis (EDS) showed Mn localization in G. bidwillii to be different from other hyperaccumulating species. Foliage hyperaccumulated metals are usually known, with rare exceptions, to accumulate in non-photosynthetic tissues, in most species in epidermal cells and in some species in trichomes and trichome bases (Vázquez et al. 1992; Küpper et al. 2000, 2001; Krämer et al. 1997; Mesjasz-Przybylowicz et al. 2001; Bhatia et al. 2003; Bidwell et al. 2004; Broadhurst et al. 2004), whereas in G. bidwillii Mn was found to be primarily localised in photosynthetic cells (Fernando et al. 2006a, $b, 2007)$. Laboratory and synchrotron micro-X-ray Fluorescence $(\mu \mathrm{XRF})$ analysis have revealed marginal accumulation of $\mathrm{Co}, \mathrm{Mn}$, and $\mathrm{Zn}$ in leaves, with localization of $\mathrm{Co}, \mathrm{Mn}$, and $\mathrm{Zn}$ in epidermal cells of $G$. fragrantissima (Abubakari et al. 2021a).

To date, no attempt has been made to examine the effects of Mn dosing treatments on G. bidwillii under controlled experimental conditions, mainly due to the relatively slow growth rate of this species. Furthermore, there has not been any study to examine tissue-level Mn distribution in G. bidwillii originating from growing on extremely high Mn-enriched soils. This study aims to: (i) measure the response of propagated G. bidwillii plants to $\mathrm{Mn}$ treatment under controlled conditions, and (ii) assess Mn (and other elements) uptake and accumulation in G. bidwillii plants from naturally occuring highly $\mathrm{Mn}$ enriched soils. By employing laboratory $\mu \mathrm{XRF}$ analysis to determine in situ distributions of $\mathrm{Mn}$ and other elements in wild G. bidwillii and Mn-dosed G. bidwillii, this study also investigates leaf tissue $\mathrm{Mn}$ distribution patterns, as well as within-species age-related distributional differences, i.e., between their young and old leaves.

\section{Results}

Elemental Concentrations in Wild and Mn-dosed G. bidwillii All plant tissue elemental concentrations presented in this study are based on dry weight (Fig. 1). The bulk elemental concentrations in young leaves, old leaves, and twigs of the wild G. bidwillii and the dosed G. bidwillii are shown in Tables 1 and 2, respectively, and that of the concentrations of Mn in young leaves, old leaves, and twigs of G. bidwillii in Fig. 2. The concentrations of Mn in the wild $G$. bidwillii were remarkably high, with a mean value of $39000 \mu \mathrm{g} \mathrm{g}^{-1}(\mathrm{SE} \pm 3540)$ in old leaves, and 24 $000 \mu \mathrm{g} \mathrm{g}^{-1}(\mathrm{SE} \pm 410)$ in young leaves and $5840 \mu \mathrm{g} \mathrm{g}^{-1}$ $(\mathrm{SE} \pm 2820)$ in the twigs $(p<0.05)$ (Table 1$)$. The concentrations of $\mathrm{Ca}$ and $\mathrm{Na}$ in wild $G$. bidwillii were higher in old leaves $\left(9250 \pm 785 \mu \mathrm{g} \mathrm{g}^{-1} \mathrm{Ca}, 710 \pm 70.0 \mu \mathrm{g} \mathrm{g}^{-1} \mathrm{Na}\right)$ than in young leaves $\left(5590 \pm 145 \mu \mathrm{g} \mathrm{g}^{-1} \mathrm{Ca}, 660 \pm 190 \mu \mathrm{g} \mathrm{g}^{-1}\right.$ $\mathrm{Na})$ and twigs $\left(4700 \pm 400 \mu \mathrm{g} \mathrm{g} \mathrm{g}^{-1} \mathrm{Ca}, 170 \pm 35.0 \mu \mathrm{g} \mathrm{g}\right.$ $\mathrm{Na}$ ) (Table 1). The concentrations of $\mathrm{Fe}$ and $\mathrm{Mg}$ in old leaves of wild G. bidwillii were $75.0 \mu \mathrm{g} \mathrm{g}^{-1} \mathrm{Fe}(\mathrm{SE} \pm 17.0)$ and $1290 \mu \mathrm{g} \mathrm{g}^{-1} \mathrm{Mg}(\mathrm{SE} \pm 108)$, respectively compared to $45 \mu \mathrm{g} \mathrm{g}^{-1} \mathrm{Fe}(\mathrm{SE} \pm 0.70)$ and $840 \mu \mathrm{g} \mathrm{g}^{-1} \mathrm{Mg}$ $(\mathrm{SE} \pm 38.0)$ in its young leaves. However, no significant difference was observed between $\mathrm{Mg}$ in old leaves and twigs of wild G. bidwillii (Table 1). Concentrations of Al were higher in old leaves $\left(200 \pm 40.0 \mu \mathrm{g} \mathrm{g}^{-1} \mathrm{Al}\right)$ than in young leaves $\left(55.0 \pm 0.85 \mu \mathrm{g} \mathrm{g}^{-1} \mathrm{Al}\right)$ and in twigs $\left(6.0 \pm 10.5 \mu \mathrm{g} \mathrm{g}^{-1} \mathrm{Al}\right)$. The concentrations of $\mathrm{K}$ were higher in young leaves $\left(9380 \pm 1040 \mu \mathrm{g} \mathrm{g}^{-1} \mathrm{~K}\right)$ than old leaves $\left(3660 \pm 160 \mu \mathrm{g} \mathrm{g}^{-1} \mathrm{~K}\right)$ and twigs $\left(2710 \pm 570 \mu \mathrm{g} \mathrm{g}^{-1} \mathrm{~K}\right)$. No significant differences $(p>0.05)$ were observed for $\mathrm{Ni}, \mathrm{P}$ and $\mathrm{Zn}$ in young leaves, old leaves, and twigs of wild $G$. bidwillii (Table 1).

In the old leaves of the Mn-dosed G. bidwillii, the mean Mn concentrations in the $\mathbf{T 4}, \mathbf{T 3}$ and $\mathbf{T} 2$ treatment levels were $24400 \mu \mathrm{g} \mathrm{g}^{-1}(\mathrm{SE} \pm 10700), 21800 \mu \mathrm{g} \mathrm{g}^{-1}(\mathrm{SE} \pm 8850)$ and $14100 \mu \mathrm{g} \mathrm{g}^{-1}(\mathrm{SE} \pm 12600)$, respectively. These concentrations are more than two-fold the Mn hyperaccumulation threshold in the $\mathbf{T} 4$ and $\mathbf{T 3}$ treatment levels (Fig. 2 and Table 2). The old leaves of $G$. bidwillii in the control (T1) had up to $10900 \mu \mathrm{g} \mathrm{g}^{-1} \mathrm{Mn}$ (mean $5490 \mu \mathrm{g} \mathrm{g}^{-1}$ ). In the young leaves, the Mn concentrations in the $\mathbf{T 4}$ and T3 treatment levels were $17100 \mu \mathrm{g} \mathrm{g}^{-1}(\mathrm{SE} \pm 8440)$ and 12 $600 \mu \mathrm{g} \mathrm{g}^{-1}(\mathrm{SE} \pm 11$ 000), respectively (Fig. 2 and Table 2). The Mn concentrations of young leaves in the $\mathbf{T} 2$ treatment level $\left(8300 \mu \mathrm{g} \mathrm{g}^{-1}\right)$ were two-fold higher than that in the control T1 (Fig. 2 and Table 2). In the twigs, the highest treatment level (T4) contained $17400 \mu \mathrm{g} \mathrm{g}^{-1}(\mathrm{SE} \pm 6690)$ $\mathrm{Mn}$, which is more than threefold higher than that in the T3 $\left(5000 \pm 1150 \mu \mathrm{g} \mathrm{g}^{-1}\right), \mathbf{T} 2\left(4300 \pm 1220 \mu \mathrm{g} \mathrm{g}^{-1}\right)$ and the control T1 $\left(2900 \pm 1300 \mu \mathrm{g} \mathrm{g}^{-1}\right)$ treatment levels (Fig. 2 and Table 2). 

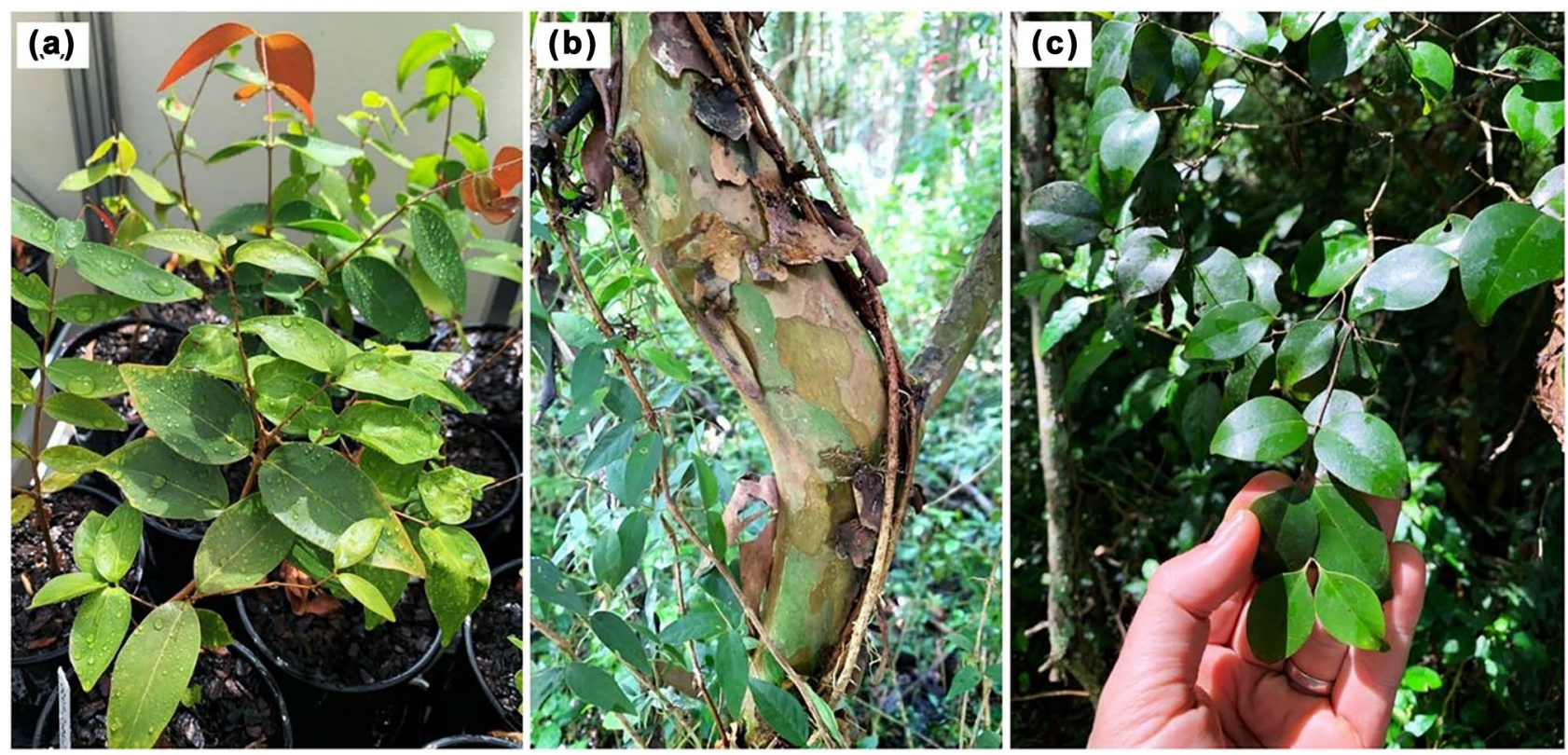

Fig. 1 Visual appearances of experimental and wild plants: (a) Experimental Gossia bidwillii, (b) field G. bidwillii tree trunk, and (c) field G. bidwillii foliage

The concentrations of $\mathrm{Ca}$ in the dosed G. bidwillii were higher in the young leaves compared to the old leaves $(p<0.05)$ (Table 2). The twigs had higher concentrations of $\mathrm{Ca}$ in the control T1, T2 and T4 treatment levels than in the young and old leaves, with mean concentrations of $17100 \mu \mathrm{g} \mathrm{g}^{-1}(\mathrm{SE} \pm 1580)$, $11100 \mu \mathrm{g} \mathrm{g}^{-1}(\mathrm{SE} \pm 2970)$ and $11700 \mu \mathrm{g} \mathrm{g}{ }^{-1}(\mathrm{SE} \pm 3780)$, respectively (Table 2). The concentrations of $\mathrm{Al}$ in old leaves of G. bidwillii were higher in the $\mathbf{T} \mathbf{3}$ and $\mathbf{T 4}$ treatment levels, with concentrations of $9000 \mu \mathrm{g} \mathrm{g}^{-1}(\mathrm{SE} \pm 5400)$ and $10700 \mu \mathrm{g} \mathrm{g}^{-1}$ ( $\mathrm{SE} \pm 5370)$, respectively, compared to that in the young leaves and twigs (Table 2). The concentrations of $\mathrm{K}$ in the control $\mathbf{T 1}$ $\left(22,100 \pm 2960 \mu \mathrm{g} \mathrm{g}^{-1} \mathrm{~K}\right)$ treatment level in young leaves was significantly higher than those observed in the other treatment levels (T2, T3, T4) in old leaves and twigs $(p<0.05)$. The concentrations of $\mathrm{Mg}$ were higher in old leaves in the control $\mathbf{T 1}$ treatment level $\left(4790 \pm 1900 \mu \mathrm{g} \mathrm{g}^{-1} \mathrm{Mg}\right)$ compared to that in the other treatment levels (T2, T3, T4) (Table 2). The concentrations of Na in twigs in the $\mathbf{T} 4$ treatment level $\left(1100 \pm 840 \mu \mathrm{g} \mathrm{g}^{-1}\right.$ $\mathrm{Na})$ were significantly higher than that in young leaves $\left(440 \pm 260 \mu \mathrm{g} \mathrm{g}^{-1} \mathrm{Na}\right)$ and old leaves $\left(630 \pm 140 \mu \mathrm{g} \mathrm{g}^{-1} \mathrm{Na}\right)$ $(p<0.05)$ (Table 2). The concentrations of Fe and $\mathrm{Zn}$ were low in all treatment levels compared to other elements in young leaves, old leaves, and twigs (Table 2). The concentrations of $\mathrm{P}$ were below the limit of detection $\left(<6.00 \mu \mathrm{g} \mathrm{g}^{-1}\right)$ in young leaves, old leaves, and twigs in all treatment levels (Table 2).

Soil Chemical Properties The soil $\mathrm{pH}$ of the wild G. bidwillii was lower $(\mathrm{pH}=4.20)$ compared to that of the Mn-dosed G. bidwillii pot soils (pH 5.27-5.95) (Table 3). Extractable
Mn concentrations for DTPA and $\operatorname{Sr}\left(\mathrm{NO}_{3}\right)_{2}$ increased with the dose levels, as expected. Variability in Mn values for DTPA and $\mathrm{Sr}\left(\mathrm{NO}_{3}\right)_{2}$ can be explained by the strong binding of $\mathrm{Mn}^{2+}$ to the organic matter of the potting mix, thereby making it less available.

$\mu$ XRF Elemental Mapping of Wild and Mn-dosed G. bidwillii Manganese in wild G. bidwillii from Mn-enriched soils in Amamoor is strongly enriched throughout the leaf blade and petiole of young and old leaves, while the veins and midrib have relatively lower concentrations (Figs. 3 and 4). Calcium and $\mathrm{K}$ are strongly enriched in the veins and midrib, with high concentrations of $\mathrm{Ca}$ in the stem and petiole and low $\mathrm{K}$ in the leaf margins of young and old leaves (Fig. 3). In the Mn-dosed G. bidwillii, the distribution of $\mathrm{Mn}$ is high at the apex and lamina, but lower in the midrib, margin, and veins (Fig. 4). However, $\mathrm{K}$ tends to be concentrated at the tip/margin, midrib, and petiole and veins whereas $\mathrm{Ca}$ is high in the midrib, margin, and veins, but lower in the leaf lamina (Fig. 4).

\section{Discussion}

Foliar Mn concentrations observed in the wild and experimental G. bidwillii were at least three-fold higher than the Mn hyperaccumulation threshold of $10000 \mu \mathrm{g} \mathrm{g}^{-1}$ (van der Ent et al. 2013), which aligns with published data for of this species (Bidwell et al. 2002; Fernando et al. 2006b; Abubakari et al. 2021a). A weak relationship between 
substrate Mn supply and foliar Mn concentrations, is also consistent with past field observations (Bidwell et al. 2002; Fernando et al. 2006b, 2007). The ability of G. bidwillii to over-accumulate $\mathrm{Mn}$, even in very low soil-supply, is a common characteristic feature for hyperaccumulators, i.e., their ability to accumulate metals in shoot tissues is consistent across a wide range of host substrate concentrations (Baker 1981; Fernando et al. 2007). The acidity of the wild G. bidwillii host soil ( $\mathrm{pH} 4.20$, Table 3 ) sampled for this study warrants consideration in the context of Mn availability at the root-soil interface. However, it is unclear why such high accumulation occurs and further investigation of specific Mn transporters associated with uptake at the root-soil interface and translocation from roots to shoots is required. It is also plausible that the apparently high Mn accumulation by wild G. bidwillii reflects specific rhizosphere effects such as acidification and/or microbial associations unique to the location that renders soil-Mn highly bioavailable.

Heterogeneity of Mn accumulation has been described in several species of the Mn hyperaccumulators; G. grayi and G. shepherdii (Fernando et al. 2013, 2018), G. hillii (Abubakari et al. 2021a, b; McLay et al. 2019), and Denhamia founieri (Fernando et al. 2008; Jaffré 1977) through field and herbarium analysis of their samples (Pollard et al. 2002; Baker et al. 1994; Macnair 2002). In contrast, the wild and Mn-dosed G. bidwillii in the present study, and previous observations through field sampling across the natural distribution and analysis of herbarium material, has found that the Mn-hyperaccumulation trait is consistent across its extensive natural range (Bidwell et al. 2002; Fernando et al. 2007).

In the Mn-dosed G. bidwillii, the behaviour of $\mathrm{Mn}$ in the oldest leaves resembled that of $\mathrm{Ca}, \mathrm{Mg}$ and $\mathrm{Na}$, which remained high at all treatment levels but contrasted with that of $\mathrm{K}$ and $\mathrm{P}$ which decreased after maturity. Similarly, in wild $G$. bidwillii, $\mathrm{K}$ was higher in young leaves than in old leaves, whereas $\mathrm{Ca}, \mathrm{Mg}, \mathrm{Na}$ and $\mathrm{Mn}$ were higher in old leaves. The high concentrations of $\mathrm{Mn}, \mathrm{Ca}, \mathrm{Mg}$ and $\mathrm{Na}$ in old leaves of the wild and Mn-dosed G. bidwillii could be attributed to phloem immobility of the aforementioned elements (Marschner 2002; Graham et al. 1988) and vice versa for $\mathrm{K}$. Moreover, this behaviour could be due to the similarities in divalent cations of $\mathrm{Mn}, \mathrm{Ca}$, and $\mathrm{Mg}$. Similar observations of high $\mathrm{Mn}$ in old leaves has been reported in G. bidwillii (Bidwell et al. 2002) and in other Mn hyperaccumulators including Phytolacca americana (Xu et al. 2006), Macadamia integrifolia (Fernando et al. 2009a), G. fragrantissima (Abubakari et al. 2021a, b) and in crop plants (Millikan 1951). In contrast, G. grayi and G. shepherdii were reported to accumulate higher Mn concentrations in young leaves than in older leaves (Fernando et al. 2018). A previous report by Bidwell et al. (2002) of decreased $\mathrm{Ca}$ and $\mathrm{Mg}$ with an increase in Mn concentration in old leaves of $G$. bidwillii contradicts the findings of this study. The nutritional 


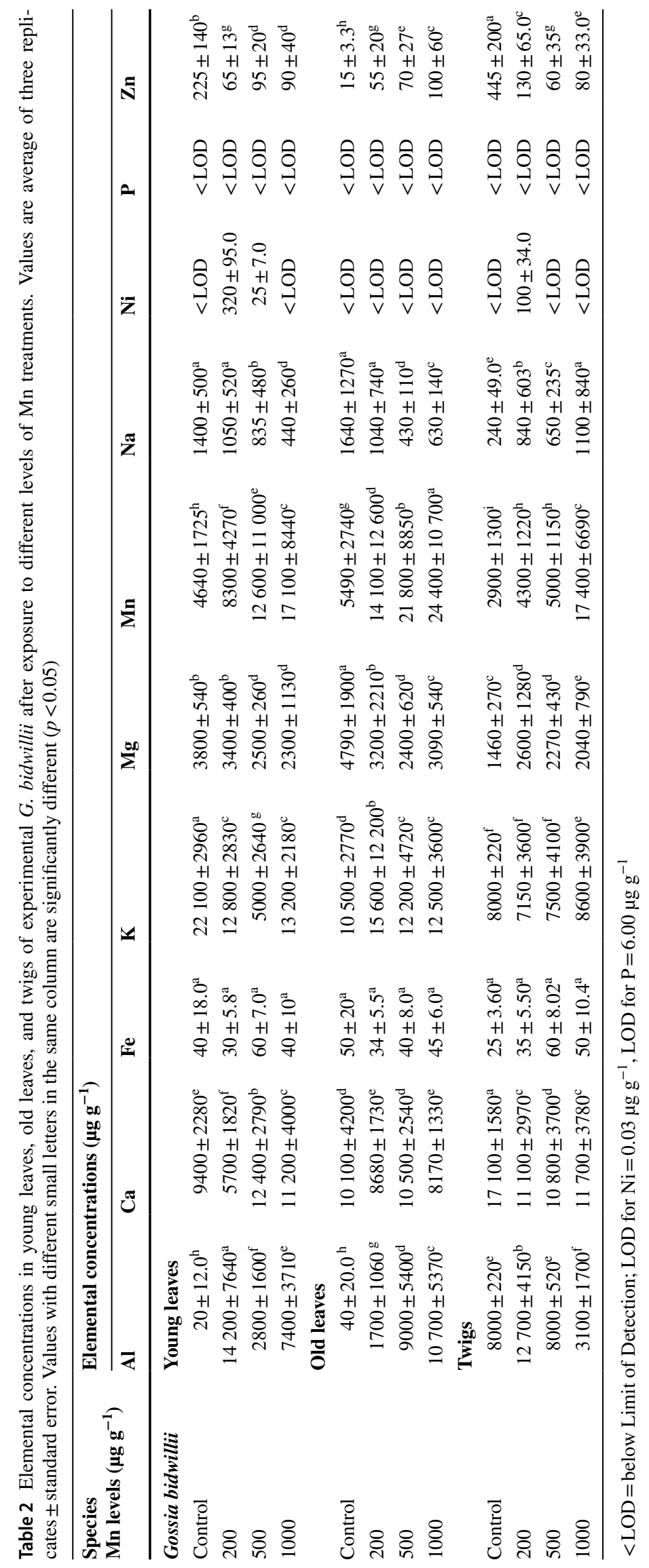




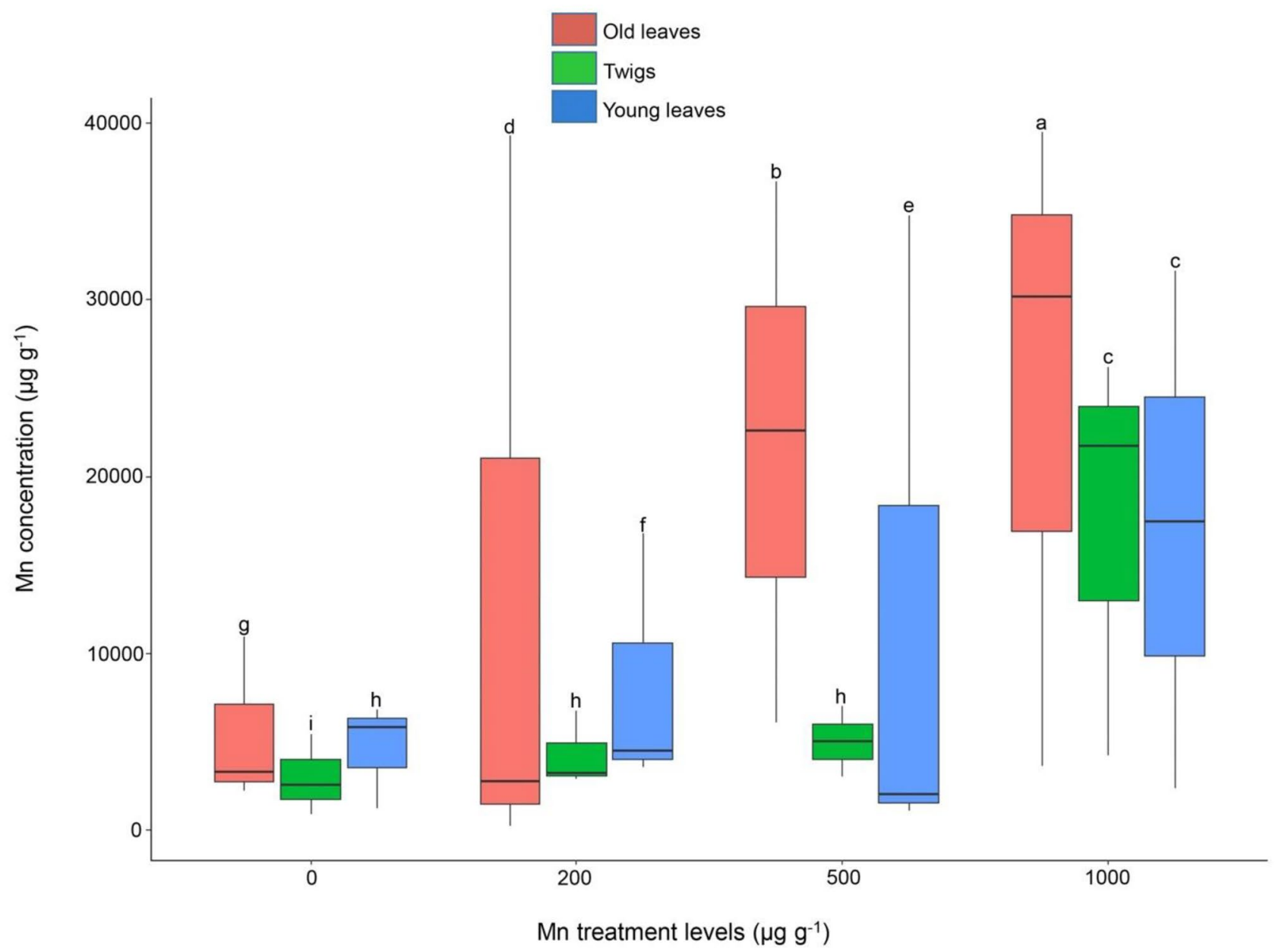

Fig. 2 Manganese concentrations in young leaves, old leaves, and twigs of experimental Gossia bidwillii plants. Keys to symbol of boxplots: open squares are the $25 \%$ to $75 \%$ quartiles, lines within the

dynamics of plants as unusual as metal hyperaccumulators are yet to be fully understood, and clearly cannot be assumed to align with broader understanding of plant nutrition largely drawn from crop models (Marschner 2002). Another possible

Table $3 \mathrm{pH}$, diethylenetriaminepentaacetic acid (DTPA) and strontium nitrate $\left(\mathrm{Sr}\left(\mathrm{NO}_{3}\right)_{2}\right)$ extractable concentrations in soils of different treatment levels of Mn of experimental G. bidwillii at harvest and soil boxes indicate the median, whereas the whiskers mark the maximum and minimum values. Values with different small letters are significantly different $(p<0.05)$

factor warranting consideration is possible seasonal shifts in foliar nutrient and metal concentrations that may contribute to observed variations across different studies.

of wild G. bidwillii. Values with different small letters in the same column are significantly different $(p<0.05)$

\begin{tabular}{|c|c|c|c|c|c|c|c|}
\hline \multirow{2}{*}{$\begin{array}{l}\text { Mn-dosed Gossia bidwillii } \\
\text { Treatment levels }\left(\mu \mathrm{g} \mathrm{g}^{-1}\right)\end{array}$} & \multirow[t]{2}{*}{ pH } & \multicolumn{3}{|c|}{ DTPA-extractable concentrations $\left(\mu \mathrm{g} \mathrm{g}^{-1}\right)$} & \multicolumn{3}{|c|}{$\mathrm{Sr}\left(\mathrm{NO}_{3}\right)_{2}$-extractable concentrations $\left(\mu \mathrm{g} \mathrm{g}^{-1}\right)$} \\
\hline & & Co & Mn & $\mathbf{Z n}$ & Co & Mn & $\mathbf{Z n}$ \\
\hline Control & 5.95 & $1.60 \pm 0.07^{\mathrm{c}}$ & $<\mathrm{LOD}$ & $32.5 \pm 4.24^{\mathrm{c}}$ & $1.00 \pm 0.01^{\mathrm{c}}$ & $<$ LOD & $7.30 \pm 1.24^{\mathrm{d}}$ \\
\hline Mn 200 & 5.80 & $5.80 \pm 0.30^{\mathrm{b}}$ & $<\mathrm{LOD}$ & $44.5 \pm 10.0^{c}$ & $1.20 \pm 0.04^{\mathrm{c}}$ & $6.52 \pm 3.40$ & $12.6 \pm 6.70^{\mathrm{b}}$ \\
\hline Mn 500 & 5.61 & $4.90 \pm 0.75^{\mathrm{b}}$ & $27.2 \pm 6.03$ & $60.0 \pm 13.4^{\mathrm{b}}$ & $3.45 \pm 0.22^{b}$ & $10.1 \pm 5.60$ & $18.9 \pm 3.40^{\mathrm{b}}$ \\
\hline Mn 1000 & 5.27 & $12.7 \pm 2.04^{\mathrm{a}}$ & $37.30 \pm 9.01$ & $126 \pm 56.07^{\mathrm{a}}$ & $6.70 \pm 1.90^{\mathrm{a}}$ & $17.8 \pm 8.01$ & $30.3 \pm 7.55^{\mathrm{a}}$ \\
\hline \multirow[t]{3}{*}{ Filed collected Gossia bidwillii } & $\mathbf{p H}$ & \multicolumn{3}{|c|}{ DTPA-extractable concentrations $\left(\mu \mathrm{g} \mathrm{g}^{-1}\right)$} & \multicolumn{3}{|c|}{$\operatorname{Sr}\left(\mathrm{NO}_{3}\right)_{2}$-extractable concentrations $\left(\mu \mathrm{g} \mathrm{g}^{-1}\right)$} \\
\hline & & Co & Mn & Zn & Co & Mn & Zn \\
\hline & 4.20 & 0.98 & 1580 & 12.2 & 0.19 & 1650 & 3.00 \\
\hline
\end{tabular}

$<\mathrm{LOD}=$ below Limit of Detection; LOD for $\mathrm{Mn}=0.07 \mu \mathrm{g} \mathrm{g}^{-1}$ 


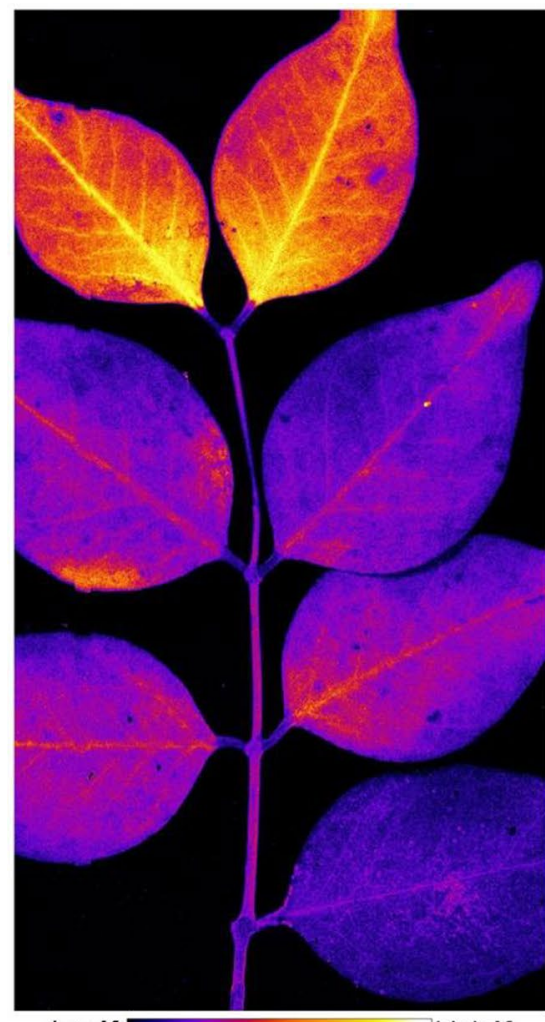

low K

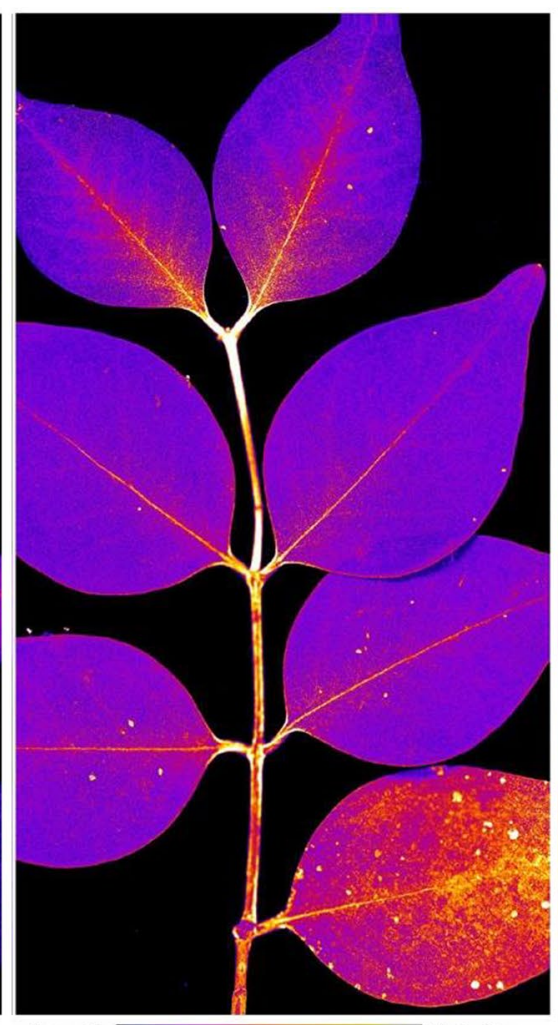

low CaI

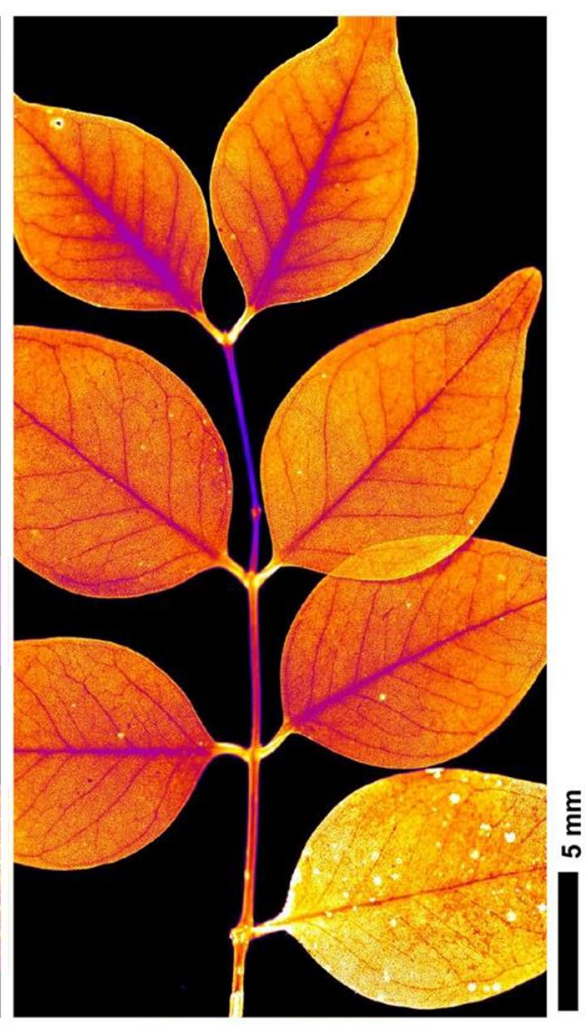

low $\mathrm{Mn}$

high Mn

Fig. 3 Laboratory $\mu$ XRF maps of $\mathrm{K}, \mathrm{Ca}$, and Mn of a whole fresh/hydrated wild G. bidwillii branchlets

The phytoavailability of $\mathrm{Al}$ and $\mathrm{Mn}$ are known to occur in soils of low $\mathrm{pH}(<5)$. However, the $\mathrm{pH}$ of soils on which the Mn-dosed G. bidwillii was cultivated in this study shows that the solubility of $\mathrm{Al}$ was low, yet G. bidwillii was able to take up high concentrations of $\mathrm{Al}$ in old leaves which qualifies it as a potential $\mathrm{Al}$ hyperaccumulator, with concentrations six-fold higher than the Al hyperaccumulation threshold set at $3000 \mu \mathrm{g} \mathrm{g}^{-1}$ (Jansen et al. 2003, 2001). Exceptionally high $\mathrm{Al}$ concentrations in old G. bidwillii leaves, even under $\mathrm{Mn}$ treatment, could be facilitated by organic anions involved in Mn transport (Bidwell et al. 2002). This suggests that $G$. bidwillii may be able to take up $\mathrm{Al}$ via an anion channel, a mechanism that appears to be a peculiar trait among Al tolerant species (Zhang et al. 2001; Ryan et al. 1997; Piñeros and Kochian 2001; Kollmeier et al. 2001). It should be cautioned here that these observations of $\mathrm{Al}$ over accumulation by $G$. bidwillii have been made under experimental conditions, and have not been observed in the field, even on lateritic soils rich in $\mathrm{Al}$ (Fernando, Bidwell etc.). The notable limit of Al uptake in wild G. bidwillii, even though the soil $\mathrm{pH}$ was suitable for Al mobilisation, was most likely due to the very low soil $\mathrm{Al}$ concentrations. Furthermore, it has also been suggested that $\mathrm{Al}$ inhibits uptake of $\mathrm{Ca}$ and $\mathrm{Mg}$ in non- $\mathrm{Al}$ accumulators (Kochian et al. 2005; Ryan and Kochian 1993; Rengel and Zhang 2003). This was an unexpected observation in old leaves of the wild G. bidwillii in this present study. This present observation of $\mathrm{Al}$ accumulation in Mn-dosed $G$. bidwillii and its absence in wild G. bidwillii warrants further investigation. Species within the Myrtaceae have been listed to contain Al hyperaccumulators (Jansen et al. 2003, 2001) and previous studies by Fernando et al. (2009b) have shown that other Gossia spp., including G. hillii, G. inophloia, G. lewensis and G. macilwraithensis, can be $\mathrm{Al}$ hyperaccumulators under experimental conditions.

The distribution patterns of $\mathrm{Mn}$ in leaves of wild G. bidwillii was strongly enriched throughout the young and old leaves (Fig. 3). In the Mn-dosed G. bidwillii, Mn was concentrated in the apical point of the leaf as well as across the broader laminal area (Fig. 4). Similar observations have been reported for the Mn hyperaccumulators Acanthopanax sciadophylloides (Memon et al. 1980), G. fragrantissima (Abubakari et al. 2021a), and D. silvestris and D. cunninghamii (Abubakari et al. 2021b). This study used a dosing trial for the first time to demonstrate the Mn-hyperaccumulation trait in G. bidwillii under controlled experimental conditions. The Mn concentrations in young leaves, old leaves, and twigs of the Mn-dosed G. bidwillii increase with increasing soil $\mathrm{Mn}$ concentrations. Laboratory $\mu \mathrm{XRF}$ analysis revealed different Mn distribution patterns in the leaves of wild and Mn-dosed G. bidwillii. Further work should be 
Fig. 4 Laboratory $\mu$ XRF maps of $\mathrm{K}, \mathrm{Ca}$, and $\mathrm{Mn}$ of fresh/ hydrated leaves of wild $G$. bidwillii (top) and Mn-dosed $G$. bidwillii (below)
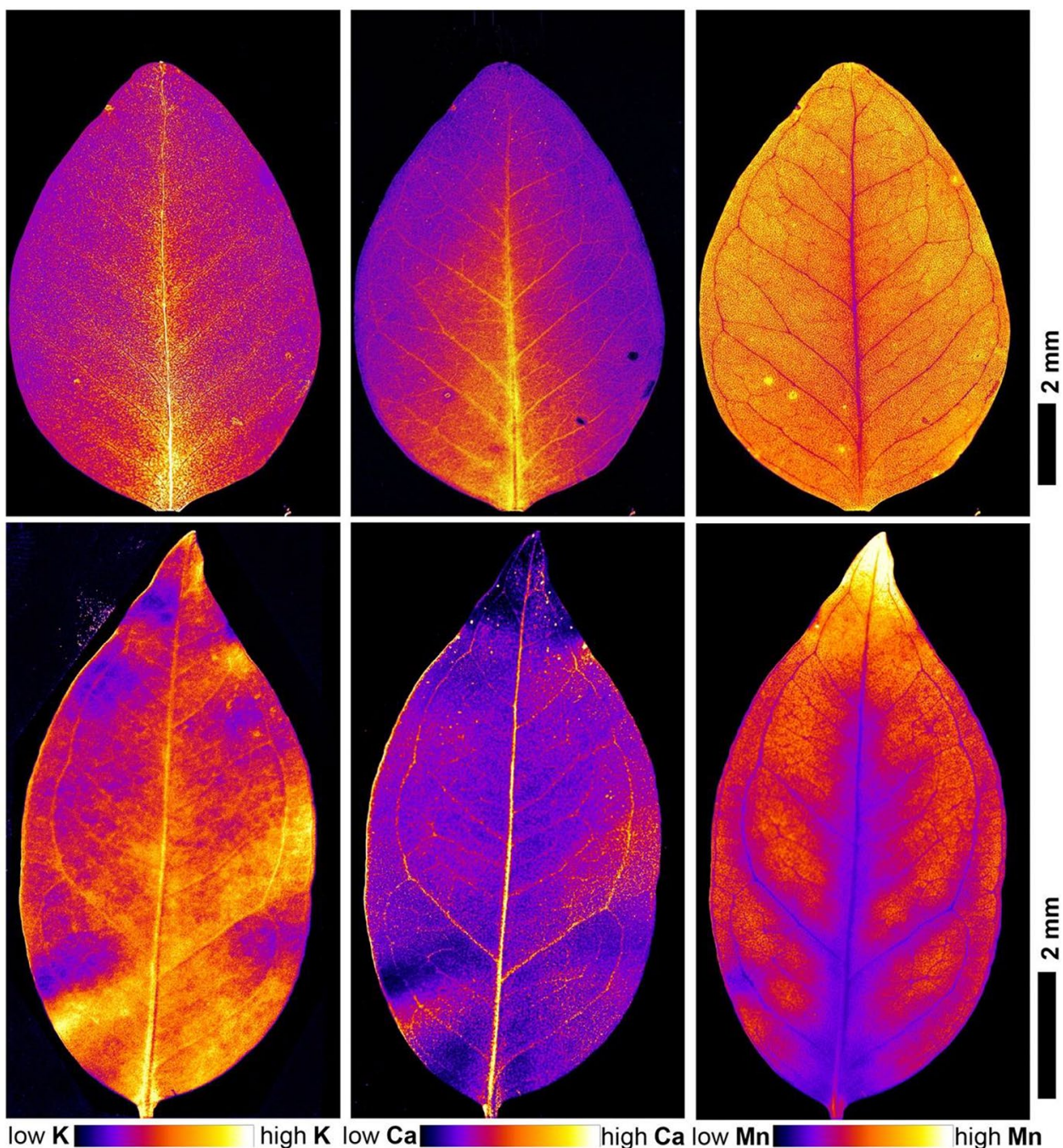

undertaken using synchrotron X-ray Fluorescence Microscopy with higher resolution to investigate Mn distribution at the cellular and subcellular levels in order to elaborate hypotheses for its metabolic pathways to be coupled to molecular biological studies (e.g., transcriptomics) to identify putative Mn-transporters in G. bidwillii.

\section{Methods}

Habitat and Ecology of the Studied Species Gossia bidwillii, grows up to $15 \mathrm{~m}$ high with a smooth trunk with "python"coloured patches. Its leaves are oval to elliptical, apex acuminate, lower surface glabrous, and oil glands densely crowded (Snow et al. 2003; PlantNET). The leaves tend to be sticky when crushed (Fig. 1). Gossia bidwillii is the most widespread Australian species in the genus and occurs from the Hunter River $\left(32^{\circ} \mathrm{S}\right)$ in New South Wales to near Coen $\left(13^{\circ} \mathrm{S}\right)$ in far northern Queensland. It mostly occurs east of the Great Dividing Range with an altitudinal range from
300-800 m (Snow et al. 2003). It grows in subtropical drier rainforests and can be very common on ridgetops and slopes in Araucarian microphyll vineforests, complex notophyll forests, semi-evergreen vineforest thickets, dry scrub, and gallery rainforests on a range of soils (Snow et al. 2003).

Plant Dosing Trial Gossia bidwillii plants, approximately $20 \mathrm{~cm}$ in height, were obtained from Coastal Dry Tropics Landcare (Pallarenda Road, Townsville, Queensland) and cultivated in a temperature and humidity-controlled glasshouse at the University of Queensland, Brisbane, Australia, Central Glasshouse Service. The plants were kept at $24^{\circ} \mathrm{C}$ and $80 \%$ Relative Humidity (RH), with a photosynthetic photon flux density at 13:00 h of $1600 \mu \mathrm{mol} \mathrm{m} \mathrm{m}^{-1}$ (measured with an Apogee MQ-500 instrument). After three weeks the plants were transferred to $15 \mathrm{~cm}$ pots containing a mixture of 9 parts composted pine bark $(5-10 \mathrm{~mm})$ and one part coco peat (Bassett Barks Pty Ltd, Queensland, Australia). Fertilisers and other additives were mixed with the potting compost at the following amounts per $\mathrm{m}^{3}$, including 
$1.2 \mathrm{~kg}$ Yates Flowtrace, $1 \mathrm{~kg}$ iron sulphate heptahydrate $\left(\mathrm{FeO}_{4} \mathrm{SO}_{4} .7 \mathrm{H}_{2} \mathrm{O}\right), 0.1 \mathrm{~kg}$ superphosphate $\left(\mathrm{Ca}\left(\mathrm{H}_{2} \mathrm{PO}_{4}\right)_{2}\right)$, $1.5 \mathrm{~kg}$ gypsum $\left(\mathrm{CaSO}_{4}\right)$, and $1.5 \mathrm{~kg}$ dolomite $\left(\mathrm{CaMg}\left(\mathrm{CO}_{3}\right)_{2}\right)$ $\left(\right.$ per $\left.\mathrm{m}^{3}\right)$. The Flowtrace contained 24 weight percent iron (Fe) as $\mathrm{FeSO}_{4}, 14$ weight percent sulphur (S) as $\mathrm{SO}_{4}, 0.75$ weight percent copper $(\mathrm{Cu})$ as $\mathrm{CuSO}_{4}, 0.5$ weight percent manganese (Mn) as $\mathrm{MnSO}_{4}, 0.2$ weight percent zinc $(\mathrm{Zn})$ as $\mathrm{ZnSO}_{4}, 0.04$ weight percent molybdenum (Mo) as $\mathrm{Na}_{2} \mathrm{MoO}_{4}, 0.033$ weight percent boron (B) as $\mathrm{Na}_{2} \mathrm{~B}_{4} \mathrm{O}_{7}$. The soils with final dosed $\mathrm{Mn}^{2+}$ concentrations of $200 \mathrm{~g} \mathrm{~g}^{-1}$ (T2), $500 \mathrm{~g} \mathrm{~g}^{-1}$ (T3), and $1000 \mathrm{~g} \mathrm{~g}^{-1}$ (T4) in addition to the control (T1) were duplicated three times, resulting in a total of 12 experimental groups. Over a period of 12 months, each treatment was given as aqueous $\mathrm{MnSO}_{4} \cdot \mathrm{H}_{2} \mathrm{O}$ solutions, with a similar volume of water added each time to the control. To avoid losses of the treatments, the individual pots were placed on saucers, and hand watered daily to field capacity.

Field Sampling Gossia bidwillii was sampled within the Amamoor State Forest in Queensland, Australia $\left(26^{\circ} 20^{\prime} 41.0^{\prime \prime} \mathrm{S} 152^{\circ} 37^{\prime} 7.0^{\prime \prime} \mathrm{E}\right)$. The geology of this area is predominantly volcanic rock (andesite) overlaying variably silicified shale or tuffs containing Mn-rich ( 30-50 wt\%) minerals such as bixbyite and pyrolusite. Krasnozem soils derived from this parent rock contain Mn to levels as high as $40 \mathrm{wt} \%$ (Isbell 1994). Old and young G. bidwillii leaves (10-20 each) were collected for total elemental analysis, while small branchlets with old and young leaves were detached and stored fresh for the laboratory $\mu \mathrm{XRF}$ analyses. Soil samples were collected from beneath the trees $(<10 \mathrm{~cm}$ depth $)$ at three different points (free of surface litter).

Chemical Analysis of Soil and Plant Samples After harvesting experimental G. bidwillii, soils were extracted in each pot and emptied into plastic bags. Soils on which wild G. bidwillii was growing were also collected as described above. All soils were air dried and later passed through a $2 \mathrm{~mm}$ sieve. After $2 \mathrm{~h}$ of shaking, the $\mathrm{pH}$ of a 1 to 2.5 soil to water mixture was determined. The extraction of immediately available trace elements uses a $0.01 \mathrm{M} \mathrm{Sr}\left(\mathrm{NO}_{3}\right)_{2}$ solution at a soil:solution ratio of $1: 4$ ( $10 \mathrm{~g}$ soil with $40 \mathrm{~mL}$ solution) and a $2 \mathrm{~h}$ shaking period were adapted from Kukier and Chaney (2001). Diethylenetriaminepentaacetic acid (DTPA) solution was used to extract "phytoavailable" trace elements, based on the original method by Lindsay and Norvell (1978), but modified as follows: no triethanolamine (TEA), $\mathrm{pH}$ set to 5.3, and $5 \mathrm{~g}$ soil with $25 \mathrm{~mL}$ extractant, with an extraction time of $1 \mathrm{~h}$.

Plant material samples were oven dried at $60{ }^{\circ} \mathrm{C}$ for three days and weighed, powdered and $300 \mathrm{mg}$ per sample digested with $4 \mathrm{~mL} \mathrm{HNO}_{3}(70 \%)$ in a microwave oven (Milestone Start D) for a 45-min programme. Digests were then brought to volume $(45 \mathrm{~mL}$ ) with ultrapure water (Millipore $18.2 \mathrm{M} \Omega \cdot \mathrm{cm}$ at $25^{\circ} \mathrm{C}$ ) for analysis with Inductively coupled plasma atomic emission spectroscopy (ICP-AES) using a Thermo Scientific iCAP 7400 instrument for macro-elements ( $\mathrm{Al}, \mathrm{Na}, \mathrm{Mg}, \mathrm{K}$, $\mathrm{P}, \mathrm{Ca})$ and trace-elements ( $\mathrm{Fe}, \mathrm{Ni}, \mathrm{Mn}, \mathrm{Co}, \mathrm{Zn})$. Certified reference material (Sigma-Aldrich Periodic Table mix 1 for ICP TraceCERT®) and Standard Reference Material (NIST Apple 1515) were used as quality controls.

Laboratory $\mu$ XRF Elemental Mapping Freshly excised branchlets from $1000 \mu \mathrm{g} \mathrm{Mn} \mathrm{g}^{-1}$ treated experimental G. bidwillii plants and from wild G. bidwillii trees from the Amamoor State Forest were used for the $\mu \mathrm{XRF}$ analysis. The University of Queensland $\mu \mathrm{XRF}$ facility contains a modified IXRF ATLAS X system with a $50 \mathrm{~W}$ X-ray source (Mo-tube producing $17.4 \mathrm{keV} \mathrm{X}$-rays) focussing to $25 \mu \mathrm{m}$ and two silicon drift detectors of $150 \mathrm{~mm}^{2}$. Measurements were conducted at atmospheric temperature $\left(\sim 20^{\circ} \mathrm{C}\right)$ and to limit dehydration, the hydrated foliar samples were tightly mounted between two sheets of $4 \mathrm{~m}$ Ultralene thin film.

Data processing and Statistical Analysis The data on the $\mu \mathrm{XRF}$ instrument were acquired in mapping mode using the instrument control package Iridium (IXRF systems) from the sum of counts at the position of the principal fluorescence peak for each element. These were each exported into ImageJ as greyscale 8-bit TIFF files, internally normalised so that each image covered the entire dynamic range and displayed using ImageJ's "Fire" lookup table. The concentrations of Mn presented as boxplots were generated using $\mathrm{R}$ version 3.6.1 (2019-07-05). Tests presented in the Tables were conducted using One-Way ANOVA and means compared with Tukey's honestly significant difference (HSD) Post Hoc Test in the IBM SPSS Statistics 27 software package (IBM, New York, USA). Values with different small letters are significantly different $(p<0.05)$.

Acknowledgements Farida Abubakari is the recipient of a UQ Graduate School Scholarship (UQGSS) from The University of Queensland. We thank Lachlan Casey (Centre for Microscopy and Microanalysis at the University of Queensland) for technical support with the $\mu \mathrm{XRF}$ analysis. The authors acknowledge the support of Microscopy Australia at the Centre for Microscopy and Microanalysis at the University of Queensland.

Author Contributions FA, PNN and AVDE designed and conducted the experiment. FA collected the samples and undertook the chemical analysis of the samples. FA, PNN and AVDE performed data processing and analysis. All authors contributed to writing of the manuscript.

Funding Open Access funding enabled and organized by CAUL and its Member Institutions. 


\section{Declarations}

Conflicts of Interest The authors have no conflicts of interest to declare that are relevant to the content of this article.

Open Access This article is licensed under a Creative Commons Attribution 4.0 International License, which permits use, sharing, adaptation, distribution and reproduction in any medium or format, as long as you give appropriate credit to the original author(s) and the source, provide a link to the Creative Commons licence, and indicate if changes were made. The images or other third party material in this article are included in the article's Creative Commons licence, unless indicated otherwise in a credit line to the material. If material is not included in the article's Creative Commons licence and your intended use is not permitted by statutory regulation or exceeds the permitted use, you will need to obtain permission directly from the copyright holder. To view a copy of this licence, visit http://creativecommons.org/licenses/by/4.0/.

\section{References}

Abubakari F, Nkrumah PN, Fernando DR, Brown GK, Erskine PD, Echevarria G, van der Ent A (2021a) Incidence of hyperaccumulation and tissue-level distribution of manganese, cobalt and zinc in the genus Gossia (Myrtaceae). Metallomics 13(4):mfab008. https:// doi.org/10.1093/mtomcs/mfab008

Abubakari F, Nkrumah PN, Erskine D, Brown GK, Fernando DR, Echevarria G, van der Ent A (2021b) Manganese (hyper) accumulation within Australian Denhamia (Celastraceae): An assessment of the trait and manganese accumulation under controlled conditions. Plant Soil 463:205-223

Baker AJM (1981) Accumulators and excluders -strategies in the response of plants to heavy metals. Journal Plant Nutri, pp. 643-654

Baker AJM (1987) Metal tolerance, New Phytol, 106, 93-111

Baker AJM, Brooks RR (1989) Terrestrial higher plants which hyperaccumulate metallic elements. A review of their distribution, ecology and phytochemistry Biorecovery, pp. 81-126

Baker AJM, Reeves RD, Hajar A (1994) Heavy metal accumulation and tolerance in British populations of the metallophyte Thlaspi caerulescens J. \& C. Presl (Brassicaceae). New Phytol 127:61-68

Bhatia NP, Orlic I, Siegele R, Ashwath N, Baker AJM, Walsh KB (2003) Elemental mapping using PIXE shows the main pathway of nickel movement is principally symplastic within the fruit of the hyperaccumulator Stackhousia tryonii. New Phytol 160:479-488

Bidwell SD, Crawford S, Woodrow IE, Sommer-Knudsen J, Marshall AT (2004) Sub-cellular localization of $\mathrm{Ni}$ in the hyperaccumulator, Hybanthus floribundus (Lindley) F. Muell. Plant, Cell Environ 27:705-716

Bidwell SD, Woodrow IE, Batianoff GN, Sommer-Knudsen J (2002) Hyperaccumulation of manganese in the rainforest tree Austromyrtus bidwillii (Myrtaceae) from Queensland, Australia. Funct Plant Biol 29:899-905

Broadhurst CL, Chaney RL, Angle JS, Maugel TK, Erbe EF, Murphy CA (2004) Simultaneous hyperaccumulation of nickel, manganese, and calcium in Alyssum leaf trichomes. Environ Sci Technol 38:5797-5802

Do C, Abubakari F, Remigio AC, Brown GK, Casey LW, BurtetSarramegna V, Gei V, Erskine PD, van der Ent A (2019) A preliminary survey of nickel, manganese and zinc (hyper) accumulation in the flora of Papua New Guinea from herbarium X-ray fluorescence scanning. Chemoecology 30:1-13

Fernando DR, Batianoff GN, Baker AJM, Woodrow IE (2006b) In vivo localization of manganese in the hyperaccumulator Gossia bidwillii (Benth.) N. Snow \& Guymer (Myrtaceae) by cryo-SEM/ EDAX. Plant Cell Environ 29:1012-1020

Fernando DR, Bakkaus EJ, Perrier N, Baker AJM, Woodrow IE, Batianoff GN, Collins RN (2006a) Manganese accumulation in the leaf mesophyll of four tree species: a PIXE/EDAX localization study. New Phytol 171:751-758

Fernando DR, Baker AJM, Woodrow IE (2009a) Physiological responses in Macadamia integrifolia on exposure to manganese treatment. Aust J Bot 57:406-413

Fernando DR, Guymer G, Reeves RD, Woodrow IE, Baker AJM, Batianoff GN (2009b) Foliar Mn accumulation in eastern Australian herbarium specimens: prospecting for 'new'Mn hyperaccumulators and potential applications in taxonomy. Ann Bot 103:931-939

Fernando DR, Woodrow IE, Jaffré T, Dumontet V, Marshall AT, Baker AJM (2008) Foliar manganese accumulation by Maytenus founieri (Celastraceae) in its native New Caledonian habitats: populational variation and localization by $\mathrm{X}$-ray microanalysis. New Phytol 177:178-185

Fernando DR, Marshall AT, Forster PI, Hoebee SE, Siegele R (2013) Multiple metal accumulation within a manganese-specific genus. Am J Bot 100:690-700

Fernando DR, Smith CS, Steinbauer MJ, Farnier K, Watson SJ, Green PT (2018) Does foliage metal accumulation influence plant-insect interactions? A field study of two sympatric tree metallophytes. Funct Plant Biol 45:945-956

Fernando DR, Woodrow IE, Bakkaus EJ, Collins RN, Baker AJM, Batianoff GN (2007) Variability of Mn hyperaccumulation in the Australian rainforest tree Gossia bidwillii (Myrtaceae). Plant Soil 293:145-152

Graham RD, Hannam RJ, Uren NC (1988) Manganese in soils and plants: Proceedings of the international symposium on manganese in soils and plants held at the waite agricultural research institute, the university of Adelaide, Glen Osmond, South Australia, August 22-26, as an Australian bicentennial event. Springer Science \& Business Media

Isbell R (1994) Krasnozems - a profile. Soil Res 32:915-929

Jaffré T (1977) Accumulation du manganèse par des especes associées aux terrains ultrabasiques de Nouvelle-Calédonie. Cr Acad Sci Paris D 284:1573-1575

Jaffré T (1980) Étude écologique du peuplement végétal des sols dérivés de roches ultrabasiques en Nouvelle Calédonie. Paris: Travaux et Documents de l'ORSTOM 124

Jansen S, Broadley MR, Robbrecht E, Smets E (2003) Aluminum hyperaccumulation in angiosperms: a review of its phylogenetic significance. Bot Rev 68:235-269

Jansen S, Lens F, Smets E (2001) Aluminium hyperaccumulation in angiosperms: distribution and phylogenetic significance. In The evolution of plant physiology - an international symposium. Kew: Linnean Society of London and The Royal Botanic Gardens

Kochian LV, Pineros MA, Hoekenga OA (2005) The physiology, genetics and molecular biology of plant aluminum resistance and toxicity. In: Lambers H (ed) Root Physiology: From Gene to Function. Kluwer Academic Publishers, Dordrecht, The Netherlands 175-196

Kollmeier M, Dietrich P, Bauer CS, Horst WJ, Hedrich R (2001) Aluminum activates a citrate-permeable anion channel in the aluminum-sensitive zone of the maize root apex. A comparison between an aluminum-sensitive and an aluminum-resistant cultivar. Plant Physiol 126:397-410

Krämer U, Grime G, Smith J, Hawes C, Baker A (1997) Micro-PIXE as a technique for studying nickel localization in leaves of the hyperaccumulator plant Alyssum lesbiacum. Nucl Instrum Methods Phys Res Sect B 130:346-350

Kukier U, Chaney RL (2001) Amelioration of nickel phytotoxicity in muck and mineral soils J Environ Qual, pp. 1949-1960 
Küpper H, Lombi E, Zhao FJ, McGrath SP (2000) Cellular compartmentation of cadmium and zinc in relation to other elements in the hyperaccumulator Arabidopsis halleri. Planta 212:75-84

Küpper H, Lombi E, Zhao FJ, Wieshammer G, McGrath SP (2001) Cellular compartmentation of nickel in the hyperaccumulators Alyssum lesbiacum, Alyssum bertolonii and Thlaspi goesingense. J Exp Bot 52:2291-2300

Lindsay WL, Norvell WA (1978) Development of a DTPA soil test for zinc, iron, manganese, and copper Soil Sci Soc Am, pp. 421-428

Losfeld G, L'Huillier L, Fogliani B, Coy SM, Grison C, Jaffré T (2015) Leaf-age and soil-plant relationships: key factors for reporting trace-elements hyperaccumulation by plants and design applications. Environ Sci Pollut Res 22:5620-5632

Macnair MR (2002) Within and between population genetic variation for zinc accumulation in Arabidopsis halleri. New Phytol 155:59-66

Marschner H (2002) Mineral nutrition of higher plants. Academic Press London

McLay T, Holmes GD, Forster PI, Hoebee SE, Fernando DR (2019) Phylogeny, biogeography and foliar manganese accumulation of Gossia (Myrtaceae). Aust Syst Bot 31:374-388

Memon AR, Chino M, Takeoka Y, Hara K, Yatazawa M (1980) Distribution of manganese in leaf tissues of manganese accumulator: Acanthopanax sciadophylloides as revealed by Electron probe X-Ray Microanalyzer. J Plant Nutr 2:457-476

Mesjasz-Przybylowicz J, Przybylowicz W, Rama D, Pineda C (2001) Elemental distribution in Senecio anomalochrous, a Ni hyperaccumulator from South Africa. S Afr J Sci 97:593-595

Millikan C (1951) Radio-autographs of manganese in plants. Aust J Biol Sci 4:28-41

Nkrumah PN, Echevarria G, Erskine PD, van der Ent A (2018) Nickel hyperaccumulation in Antidesma montis-silam: from herbarium discovery to collection in the native habitat. Ecol Res 33:675-685

Piñeros MA, Kochian LV (2001) A patch-clamp study on the physiology of aluminum toxicity and aluminum tolerance in maize.
Identification and characterization of $\mathrm{Al}^{3+}$-induced anion channels. Plant Physiol 125:292-305

Pollard AJ, Powell KD, Harper FA, Smith JAC (2002) The genetic basis of metal hyperaccumulation in plants. Crit Rev Plant Sci 21:539-566

Reeves RD (2003) Tropical hyperaccumulators of metals and their potential for phytoextraction. Plant Soil 249:57-65

Rengel Z, Zhang WH (2003) Role of dynamics of intracellular calcium in aluminium-toxicity syndrome. New Phytol 159:295-314

Ryan PR, Kochian LV (1993) Interaction between aluminum toxicity and calcium uptake at the root apex in near-isogenic lines of wheat (Triticum aestivum L.) differing in aluminum tolerance. Plant Physiol 102:975-982

Ryan PR, Skerrett M, Findlay GP, Delhaize E, Tyerman SD (1997) Aluminum activates an anion channel in the apical cells of wheat roots. Proc Natl Acad Sci 94:6547-6552

Snow N, Guymer GP, Sawvel G (2003) Systematics of Austromyrtus, Lenwebbia, and the Australian species of Gossia (Myrtaceae). Syst Bot Monogr 1-95

van der Ent A, Baker AJM, Reeves RD, Pollard AJ, Schat H (2013) Hyperaccumulators of metal and metalloid trace elements: facts and fiction. Plant Soil 362:319-334

Vázquez MD, Barceló J, Poschenrieder Ch, Madico J, Hatton P, Baker AJM, Cope GH (1992) Localization of zinc and cadmium in Thlaspi caerulescens (Brassicaceae), a metallophyte that can hyperaccumulate both metals. J Plant Physiol 140:350-355

Xu X, Shi J, Chen Y, Chen X, Wang H, Perera A (2006) Distribution and mobility of manganese in the hyperaccumulator plant $P h y$ tolacca acinosa Roxb. (Phytolaccaceae). Plant Soil 285:323-331

Zhang W-H, Ryan PR, Tyerman SD (2001) Malate-permeable channels and cation channels activated by aluminum in the apical cells of wheat roots. Plant Physiol 125:1459-1472

Publisher's Note Springer Nature remains neutral with regard to jurisdictional claims in published maps and institutional affiliations. 